\title{
Isolation, Characterization and Physicochemical Properties of Starch from Ginger (Zingiber Officinale)
}

\author{
Praveen N. M. ${ }^{1}$, Manasa S. ${ }^{2}$, Kiran B. Muchadi $^{3}$, \& Sathish Kumar B. Y. ${ }^{4}$ \\ ${ }_{1,2,3,4}$ Postgraduate Department of Biotechnology, \\ JSS College, Ooty Road, Mysuru, Karnataka, India-570025. \\ E-Mail:pravis087@gmail.com
}

Type of the Paper: Case Report.

Type of Review: Peer Reviewed.

Indexed In: OpenAIRE.

DOI: http://doi.org/10.5281/zenodo.2586237.

Google Scholar Citation: IJHSP

\section{How to Cite this Paper:}

Praveen, N. M., Manasa, S. Muchadi, Kiran B., \& Sathish Kumar, B. Y. (2019). Isolation, Characterization and Physicochemical Properties of Starch from Ginger (Zingiber Officinale). International Journal of Health Sciences and Pharmacy (IJHSP), 3(1), 13-17. DOI: http://doi.org/10.5281/zenodo.2586237.

International Journal of Health Sciences and Pharmacy (IJHSP)

A Refereed International Journal of Srinivas University, India.

(C) With Authors.

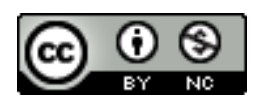

This work is licensed under a Creative Commons Attribution-Non Commercial 4.0 International License subject to proper citation to the publication source of the work.

Disclaimer: The scholarly papers as reviewed and published by the Srinivas Publications (S.P.), India are the views and opinions of their respective authors and are not the views or opinions of the SP. The SP disclaims of any harm or loss caused due to the published content to any party. 


\title{
Isolation, Characterization and Physicochemical Properties of Starch from Ginger (Zingiber Officinale)
}

\author{
Praveen N. M. ${ }^{1}$, Manasa S. ${ }^{2}$, Kiran B. Muchadi ${ }^{3}$, \& Sathish Kumar B. Y. ${ }^{4}$ \\ ${ }^{1,2,3,4}$ Postgraduate Department of Biotechnology, \\ JSS College, Ooty Road, Mysuru, Karnataka, India-570025. \\ E-Mail:pravis087@gmail.com
}

\begin{abstract}
Ginger (Zingiber officinale) contains constituent like starch, fat, gingerol, volatile oil, the crushed ginger root and starch extracted based on properties of physicochemical that isolates using $1 \% \mathrm{w} / \mathrm{v}$ sodium metabisulphite solution of achieving starch was initiate to be crystalline, non-hygroscopic powder with 1.3 swelling powder capacity, 37\% of solubility capacity and gelatinization temperature at $80^{\circ} \mathrm{C}$. The character study of starch was extracted and showed physicochemical properties elevate using extraction, purification, concentration, physical or biological process expressed for identification of sinking and non-reducing carbohydrates.
\end{abstract}

Keywords: Zingiber officinale, Physicochemical, Reducing Substance, Antioxidant.

\section{INTRODUCTION :}

Ginger (Zingiber officinale) is a herbaceous persistent plant of the family Zingiberaceae, which is used worldwide in cooking and traditional medicine with exceptional acidity and typical aroma. The increased consumption of food supplements is recognized as a nonpharmacological treatment. It is commonly used for the treatment of stomachache, arthritis, and nausea. Starch is solitary prolific organic chemicals that synthesize amyloplasts of seeds, grains, roots, and leaves of green plants in the plasmids that serve as an elementary storage form of energy from the sun. Starch recognized as biodegradable and biopolymer of the digestible polysaccharide of renowned nutritional superior to a low molecular weight of carbohydrate or sugar [1]. The World Health Organization (WHO), traditional plants are used as a complementary medicine used in pharmaceutical products coupled with desire traditional medicine used for quality and traceability of botanical element in food enhancement [2-3]. Ginger has antibacterial resistance used for traditional medicine of Zingiberaceae family that strengthen gastrointestinal (GI) disorder such as dyspepsia, to cure upper intestine ulcers include gastritis and peptic ulcer disease (PUD) caused due to bacterial infection (BI)
[4-5].

The carbohydrates consist of large glucose units of polysaccharides which can produce using green plants as an energy store. The purest form of starch viewed as white, unsavory and unscented powders which are inexplicable in cold water or alcohol. Ginger component act as tough antioxidants and valuable antimicrobial agents used primary sources gastritis and peptic ulcer in the gramnegative bacterium [6-7]. Ginger inhibits numerous pro-inflammatory cytokines includes Interleukine-1 (IL-1), Tumor necrosis factor alpha (TNF- $\alpha$ ) and Interleukine-8 (IL-8) with hamper prostaglandin (PG) and leukotriene (LT) synthesis enzymes, they expressed with gene encoding cytokines. They are conventional non-steroidal antiinflammatory drugs (NSAIDs) [8].

The present study observed physicochemical and functional properties of ginger form extracted starch that can elevate using extraction, purification, concentration, physical or biological process expressed for identification of reducing and non reducing carbohydrates.

\section{MATERIALS AND METHODS :}

2.1 Materials

The fresh sample of Ginger root was collected 
from the local area of Mysuru district, Karnataka. The samples were cleaned and packed in a sealed container at room temperature until needed.

\subsection{Purification and Isolation of Starch from Ginger (Zingiber Officinale)}

The fresh $2 \mathrm{~kg}$ of ginger roots were brought peeled and washed,the sample before chopped into tiny pieces and soaked in $1 \%$ of sodium metabisulphite solution in 1 liters of distilled water at room temperature at $25^{\circ} \mathrm{C}$. Thereafter, a scrap of root were impassive and drench pulverized aninto slurry using a grater. The paste was discrete througha hugeamount of $1 \%$ sodium metabisulphiteis filtered in muslin cloth. The deferment was centrifuged at 3500rpm for 10 minutes to assist for the exclusion of dirty, the supernatant was carefully decanted and the mucilage scraped off, repeatfour times with the mucilage on the starch tatteredconstantlyin anticipation of a pure starch was obtained. The starch was auxiliary dried at $60^{\circ} \mathrm{C}$ in a hot air oven, minced, evaluate and stored in a sample bottle for analysis [9].

\subsection{Determination of Swelling Power}

Starch sample $(0.1 \mathrm{gm})$ was evaluated in a test tube and $10 \mathrm{ml}$ of distilled water was added. The mixture was heated in water bath at a room temperature of $50^{\circ} \mathrm{C}$ for 30 minutes with uninterrupted shaking. The test tube was centrifuged at 1500rpm for 20 minutes in order to facilitate the removal of the supernatant which was carefully decanted and the weight of the starch paste taken. The swelling power was calculated as follows:

$$
\text { Swelling Power }=\underline{\text { Weight of Starch Paste }}
$$

This was carried out over a temperature range of $50^{\circ} \mathrm{C}$.

\section{Determination of Solubility Power}

Solubility index was determined over a temperature range of $50^{\circ} \mathrm{C}$ as follow: starch sample $(0.5 \mathrm{gm})$ was added to $10 \mathrm{ml}$ distilled water in a test tube. This was subjected to heating in a water bath with a starting temperature of $50^{\circ} \mathrm{C}$ for 30 minutes. Thereafter, it was centrifuged at $1500 \mathrm{rpm}$ for 30 minutes. $5 \mathrm{ml}$ of the supernatant was decanted and dried to constant weight. The solubility was expressed as the percentage (\%) by weight of dissolved starch from heated solution.

$$
\begin{aligned}
& \text { \% Solubility }=\frac{\text { Weight of the Starch Paste }}{\text { Weight of sample of Dry basis }} \times 100 \\
& \text { pH }
\end{aligned}
$$

A $20 \% \mathrm{w} / \mathrm{v}$ dispersion of the sample was shaken in water for 5 minutes and the $\mathrm{pH}$ was determined using $\mathrm{pH}$ meter.

\subsection{Gelatinization Temperature}

This was evaluated using the starch sample ( $0.5 \mathrm{gm}$ ) was put in a $20 \mathrm{ml}$ beaker and $5 \mathrm{ml}$ of distilled water added. The dispersion was heated on a hot plate. The gelatinization temperature was then read with a thermometer suspended in starch slurry [10].

\subsection{Foam Capacity}

Sample (1 gm) was homogenized in $50 \mathrm{ml}$ distilled water using vortex mixer for 5 minutes. The homogenate was poured into a $100 \mathrm{ml}$ measuring cylinder and the volume recorded after 30 seconds. The foam capacity was expressed as the percent increase in volume.

$$
\text { Foam Calculation }=\frac{\text { Average change in Volume }}{\text { Initial Volume }} \times 100
$$

\section{Test for Carbohydrates}

\section{Molish's Test}

Take $2 \mathrm{ml}$ of ginger extract solution was treated with few drops of Molish's reagent in a test tube and $2 \mathrm{ml}$ of conc. $\mathrm{H}_{2} \mathrm{SO}_{4}$ was added carefully along the side of tubes the formation of reddish violet ring at the junction of two layers indicates the presence of carbohydrates.

\section{Test for Reducing Sugar}

\section{Benedict's test}

Take $2 \mathrm{ml}$ of benedict's reagent in a clean test tube add $1 \mathrm{ml}$ of extract was added, warmed and allowed to stand for 2 min, that gets red precipitate indicates the presence of sugar.

\section{Fehling's Test}

Mix the equal volume of $(5 \mathrm{ml})$ extract solution and same volume of fehlings solution (equal mixture of fehlings solution $\mathrm{A}$ and $\mathrm{B}$ ) and boil it. After few minute the appearance of brick red precipitate, it indicates the presence of reducing sugar.

\section{Test for Monosaccharides Barfoed's Test}

In a clean test add equal volume of extract and barfoeds reagent test solution. Allow it toheat for 1-2 minutes in a water bath and cool. The existence of red precipitate indicates the presence of monosaccharide.

Test for Hexose Sugar

Selwinoff's Test 
Take a clean test tube add $3 \mathrm{ml}$ Selwinoff's reagent gently heat it later add $1 \mathrm{ml}$ test solution in bearing water bath for 1-2 minutes. Observe red color formation.

Test for Non-Reducing Sugars

\section{Benedicts Test}

Take $2 \mathrm{ml}$ of Benedict's reagent and $1 \mathrm{ml}$ of extract was added, allow for warming for few minutes in stand; formation of red precipitate indicates the presence of sugar.

Test for Non-Reducing Polysaccharides Iodine Test

Table 1 : Physicochemical Properties of Ginger Starch

\begin{tabular}{|c|c|}
\hline \multicolumn{2}{|c|}{ Physicochemical Properties of Ginger Starch } \\
\hline Parameters & Ginger \\
\hline $\mathrm{pH}$ & $6.2 \pm 0.2$ \\
\hline Gelatinization Temperature $\left({ }^{\circ} \mathrm{C}\right)$ & $80 \pm 0.02$ \\
\hline Foam Capacity $(\%)$ & $4 \pm 0.1$ \\
\hline Swelling Capacity & 1.3 \\
\hline Solubility Capacity & $37 \%$ \\
\hline
\end{tabular}

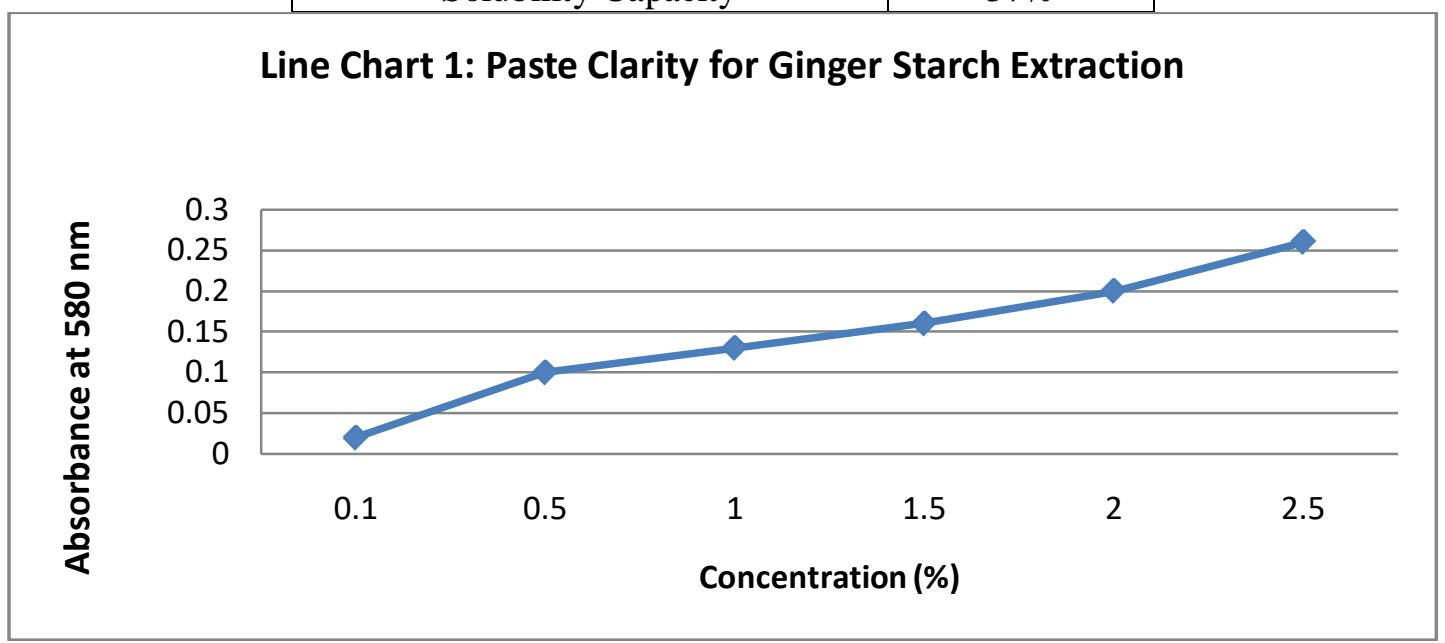

Fig 1 : : Paste Clarity for Ginger Starch Extraction

Table 2 : Screening of extract Rhizome of Ginger using Photochemical Methods

\begin{tabular}{|c|c|c|}
\hline S.No & Chemical Test & Remark \\
\hline 01. & $\begin{array}{r}\text { Test for Carbohydrates } \\
\text { a) Molishs Test } \\
\text { b) Fehling Test } \\
\text { c) Benedicts Test }\end{array}$ & $\begin{array}{c}\text { Positive } \\
\text { Negative } \\
\text { Negative }\end{array}$ \\
\hline 02. & $\begin{array}{r}\text { Test for Monosaccharide } \\
\text { a) Barfoed's Test }\end{array}$ & Negative \\
\hline 03. & $\begin{array}{r}\text { Test for Hexose Sugar } \\
\text { a) Selwinoff's Sugar }\end{array}$ & Positive \\
\hline 04. & $\begin{array}{r}\text { Test for Non-Reducing Sugar } \\
\text { a) Benedicts Test }\end{array}$ & Negative \\
\hline 05. & $\begin{array}{r}\text { Test for Non-Reducing Polysaccharides } \\
\text { a) Iodine Test }\end{array}$ & Positive \\
\hline
\end{tabular}




\section{CONCLUSION :}

The present study the starch was extracted from Zingerofficinale by using centrifugation, physicochemical properties of ginger starch was found to be white, tasteless, the swelling and solubility profile, water holding capacity, paste clarity, foam capacity, $\mathrm{pH}$, and gelatinization temperature of ginger starch was found. There starch indicates the presence of carbohydrates.

\section{Abbreviation}

World Health Organization (WHO), Peptic Ulcer Disease (PUD), Gastrointestinal (GI), Bacterial Infection (BI), Interleukin (IL), Tumor Necrosis Factor Alpha (TNF- $\alpha$ ), Prostaglandin (PG), Leukotriene (LT), NonSteroidal Anti-Inflammatory Drugs (NSAID).

\section{Consent for publication}

The authors declare that this article is original, has never been published, and has not been submitted to any other journal.

\section{Ethics approval and consent to participate}

Not applicable

\section{Authors' contribution}

PNM, MS and KBM wrote the manuscript, SKBY edited and finalized the manuscript. All authors read and approved the final manuscript.

\section{Competing interests}

The authors declare that they have no competing interest.

\section{Author information}

Praveen N. M., Kiran B. Muchadi and Manasa S. are P. G. Diploma in Protein Expression \& Scale Up, Department of Biotechnology, JSS Arts, Science and Commerce College (Ooty Road), Mysuru, Karnataka, India-570025. Sathish Kumar B. Y. Head of Department, Department of Biotechnology, JSS Arts, Science and Commerce College (Ooty Road), Mysuru, Karnataka, India-570025.

\section{REFERENCES :}

[1] Zhu, J., Chen, H., Song, Z., Wang, X., \& Sun, Z. (2018). Effects of Ginger (Zingiberofficinale Roscoe) on Type 2 Diabetes Mellitus and Components of the Metabolic Syndrome: A Systematic Review and Meta-Analysis of Randomized Controlled Trials. Evidence-Based Complementary and Alternative Medicine, 2018.
(2018). How Safe Is Ginger Rhizome for Decreasing Nausea and Vomiting in Women during Early Pregnancy?. Foods, 7(4), 50.

[3] Mahady, G. B., Pendland, S. L., Yun, G. S., Lu, Z. Z., \& Stoia, A. (2003). Ginger (Zingiberofficinale Roscoe) and the gingerols inhibit the growth of Cag A+ strains of Helicobacter pylori. Anticancer research, 23, 3699.

[4] Wagesho, Y., \& Chandravanshi, B. S. (2015). Levels of essential and non-essential metals in ginger (Zingiber officinale) cultivated in Ethiopia. SpringerPlus, 4(1), 107.

[5] Akinyemi, A. J., Adedara, I. A., Thome, G. R., Morsch, V. M., Rovani, M. T., Mujica, L. K. S., ... \& Schetinger, M. R. C. (2015). Dietary supplementation of ginger and turmeric improves reproductive function in hypertensive male rats. Toxicology reports, 2, 1357-1366.

[6] Poeloengan, M. (2011). The effect of red ginger (Zingiber officinale Roscoe) extract on the growth of mastitis causing bacterial isolates. African Journal of Microbiology Research, 5(4), 382-388.

[7] Moussa, A., Noureddine, D., Hammoudi, S. M., Saad, A., Bourabeh, A., \& Houari, H. (2012). Additive potential of ginger starch on antifungal potency of honey against Candida albicans. Asian Pacific journal of tropical biomedicine, 2(4), 253.

[8] Mahluji, S., Ostadrahimi, A., Mobasseri, M., Attari, V. E., \& Payahoo, L. (2013). Antiinflammatory effects of Zingiber officinale in type 2 diabetic patients. Advanced pharmaceutical bulletin, 3(2), 273.

[9] Zhu, L. J., Liu, Q. Q., Sang, Y., Gu, M. H., \& Shi, Y. C. (2010). Underlying reasons for waxy rice flours having different pasting properties. Food Chemistry, 120(1), 94-100.

[10] Chanapamokkhot, H., \& Thongngam, M. (2007). The chemical and physico-chemical properties of sorghum starch and flour. Kasetsart J Nat Sci, 41, 343-349.

[11] Zobel, H. F. (1988). Starch crystal transformations and their industrial importance. Starch-Stärke, 40(1), 1-7.

[2] Stanisiere, J., Mousset, P. Y., \& Lafay, S. 